\title{
Herbage response to precipitation in central Alberta boreal grasslands
}

\author{
EDWARD W. BORK, TAMIKO THOMAS, AND BRENT MCDOUGALL
}

Authors are assistant professor and past graduate, Agricultural, Food, \& Nutritional Science Department, University of Alberta, Edmonton, Alberta, Canada, T6G 2P5, and Park Warden, Elk Island National Park, Box 7, Site 4, R.R. 1, Fort Saskatchewan, Alberta, T8L $2 N 7$.

\begin{abstract}
The dependence between grassland herbage production and precipitation within the Boreal region of central Alberta was evaluated. Additional objectives were to compare current year growing season (e.g., April or May, to August) precipitation with 12 and 16 month water year (e.g., dormant and growing season) precipitation for use in predicting herbage growth, and determine whether lowland and upland grasslands differ in their response to precipitation. Lowland herbage production averaged $6,053 \mathrm{~kg} \mathrm{ha}^{-1}$, nearly twice the $3,153 \mathrm{~kg} \mathrm{ha}^{-1}$ found on upland grasslands during the study. In general, herbage production correlated significantly with precipitation, but the magnitude and direction of that relationship varied depending on grassland type. Uplands displayed a positive linear relationship with precipitation $(r=0.76 ; p<0.01)$, while lowland communities displayed a negative curvilinear $\left(R^{2}=0.65 ; p<0.05\right)$ relationship. Furthermore, while herbage production on uplands was better predicted by current year precipitation, lowland production appeared more heavily dependent on precipitation falling during the water year, the latter of which included fall and winter moisture recharge. We hypothesize that these differences are linked to water redistribution within the landscape, along with subsequent soil temperature regimes and the length of effective growing season. Given the influence of topography in regulating water availability and use, rangeland managers within the Boreal region should use caution when determining rangeland carrying capacity from meteorological data.
\end{abstract}

Key Words: current year precipitation, lowlands, production, regression, uplands, water year

Maximum allowable stocking rates on rangeland are primarily determined by forage availability, which in turn is influenced by growing conditions. Although factors such as soil development can affect rangeland production (Cannon and Nielson 1984, Epstein et al. 1997), precipitation is perhaps the single most important determinant of forage production (Clarke et al. 1947, Coupland 1958, Lauenroth and Sala 1992). In particular, variability in forage production has been linked to fluctuations in precipitation within numerous studies conducted on both Shortgrass and Mixed Prairies (e.g., Rogler and Haas 1947, Smoliak 1956, 1986, Rauzi 1964, Hulett and Tomanek 1969, Epstein et al. 1997).

The authors would like to thank 2 anonymous reviewers for their helpful comments on earlier versions of the manuscript.

Manuscript accepted 18 Jul. 2000.

\section{Resumen}

Se evaluó la dependencia entre la producción de forraje del pastizal y la precipitación dentro de la región Boreal de la parte central de Alberta. Objetivos adicionales fueron comparar la precipitación de la estación de crecimiento del año actual (esto es, Abril o Mayo a Agosto) con la precipitación de 12 y 16 meses de agua año (esto es, estaciones de crecimiento y dormancia) para usarlos en predecir el crecimiento del forraje y determinar si los pastizales de tierras bajas y altas difieren en su respuesta a la precipitación. Durante el estudio la producción de forraje en tierras bajas promedió $6,053 \mathrm{~kg} \mathrm{ha}^{-1}$, casi el doble de los $3,153 \mathrm{~kg}$ $\mathrm{ha}^{-1}$ registrados en los pastizales de tierras altas. En general la producción de forraje se correlaciono significativamente con la precipitación, pero la magnitud y dirección de esa relación varió dependiendo del tipo de pastizal Las tierras altas mostraron una relacion lineal positiva con la precipitación $\left(R^{2}=0.76 ; p<0.01\right)$ mientras que las comunidades de tierras bajas mostraron una relación curvilínea negativa $\left(R^{2}=0.65 ; p<0.05\right)$. Además, mientras la producción de forraje en las tierras altas fue predicha mejor con la precipitación del año actual, la produccion de las tierras bajas parecio ser más dependientes de la precipitación caida en el año agua, el cual incluye la recarga de humedad de otoño e invierno. Hipotetizamos que estas diferencias estan ligadas a la redistribución del agua dentro del paisaje junto con los subsecuentes regímenes de temperatura del suelo y la longitud de la estación efectiva de crecimiento. Dada la influencia de la topografía en regular la disponibilidad y uso del agua, los manejadores de pastizales dentro de la región Boreal deben tener cuidado cuando determinen la capacidad de carga del pastizal a partir de datos meteorológicos.

Furthermore, these climatic influences may continue to regulate standing crop levels despite the application of various mechanical improvements (Haferkamp et al. 1993). The ultimate utility of precipitation data for explaining changes in primary production may be linked, however, to annual variation in the pattern of rainfall including its timing and frequency of occurrence (Ballard and Ryerson 1973).

The Boreal region is the largest forested zone in central Canada, covering up to $75 \%$ of the country (Rowe 1959). Nearly $40 \%$ of Alberta falls into the Dry and Central Boreal Mixedwood Ecoregions alone (Strong 1992), with upland vegetation dominated by trembling aspen (Populus tremuloides Michx*), paper birch (Betula papyrifera Marsh.), and white spruce (Picea glauca

\footnotetext{
*Nomenclature follows E.H. Moss (1983), Flora of Alberta, Univ. of Toronto Press.
} 
[Moench] Voss). Jackpine (Pinus banksiana Lamb.) are common on sandy soils, and black spruce (Picea mariana [Mill.] BSP.), willows (Salix spp.) and sedges (Carex spp.) thrive in poorly drained areas. In general, open grasslands are confined to lowlands (e.g., wet meadow vegetation), or uplands where topographic and soil conditions, coupled with disturbances such as fire and grazing, restrict the encroachment of forest vegetation (Willoughby et al. 1996). Although only a small fraction of the typical boreal landscape consists of open grasslands, these areas produce a disproportionately large amount of the herbaceous forage available for ungulates. In British Columbia alone, wetlands have been estimated to provide up to $50 \%$ of the total forage needs for $25 \%$ of the beef cow herd (Van Ryswyk et al. 1995). As a result, these areas are the focus of considerable attention for both livestock and wildlife managers.

Despite the documented importance of the link between precipitation and productivity in prairie grasslands, little information exists on the relationship between precipitation and herbage production within grassland environments of the boreal region. Boreal rangelands, being dominated by forested vegetation and having precipitation:evapotranspiration $(\mathrm{P}: \mathrm{E})$ ratios equal or greater than 1.0 (Strong 1992), are often perceived as being non-limiting in moisture. This notion is untested, however, and additionally appears to make the assumption that drought management within the region is less of a concern during rangeland planning. Better information on the relationship between precipitation and herbage production would address this notion, as well as provide greater insight into the ecological response of these plant communities to climatic factors. Ultimately, this information could improve the ability of rangeland managers to use climatic variables such as precipitation to predict herbage growth, set appropriate long-term stocking rates, as well as anticipate potential shortages in forage availability.

Specific objectives of this study were to, (1) determine the effect of precipitation on boreal grassland herbage production, (2) compare the effects of current year and water year precipitation on herbage production, and (3) differentiate between the response of upland and lowland herbage production to inter-annual variation in precipitation.

\section{Study Area}

Elk Island National Park (EINP) was chosen as the site to address the above objectives. The park is situated near the southern limit of the Lower Boreal Mixedwood ecoregion (Strong 1992), directly adjacent to the Aspen Parkland. This area was chosen because data were readily available for individual plant communities from a long-term herbage monitoring program initiated in 1984 to assess carrying capacity throughout the Park. Furthermore, assessment of the relationship between precipitation and herbage production has direct relevance for Park managers given the relationship of herbage production to carrying capacity.

EINP is the only fenced National Park in Canada, and combined with the absence of large predators and abundant populations of bison, deer, elk, and moose, this Park faces the unique challenge of intensively managing ungulate populations (Telfer 1972). To avoid the die-offs that have historically occurred, surplus animal numbers are identified through annual aerial surveys, and removed with live trapping during the winter (Blyth and Hudson 1987). All of these management actions, however, are predicated on an accurate assessment of carrying capacity within the Park, as well as an understanding of how carrying capacity may fluctuate between years. Changes through time are particularly important as the greatest limitation in available forage occurs during winter (Bork et al. 1997), which is determined primarily by the success of plant growth the previous summer.

Given the need for detailed information regarding the status of available forage resources, a plan was implemented in 1984 that involved the annual monitoring of grassland composition and production from a fixed set of rangeland plant communities over time. This monitoring plan had 2 major objectives: provide an indication as to the extent of degradation in grasslands associated with potential overgrazing, and document changes in grassland carrying capacity through time so that animal numbers may be adjusted appropriately. The detection of significant reductions in total forage availability might allow Park managers sufficient opportunity (if necessary) to reduce ungulate populations. More recent reductions to manpower within the Park, however, have threatened the continuation of this rangeland monitoring program. As a result, alternative methods are being sought to reliably predict forage availability, including the use of climatic variables. This information would enable managers to bypass the labor intensive and expensive task of sampling individual plant commu- nities throughout the Park, while still tracking short-term changes in ungulate carrying capacity.

Elk Island National Park is situated within the Beaver Hills $\left(53^{\circ} 35^{\prime} \mathrm{N}\right.$, $112^{\circ} 50^{\prime} \mathrm{W}$ ) of central Alberta, approximately $40 \mathrm{~km}$ east of Edmonton, Alberta, Canada. The Beaver Hills are part of the Cooking Lake Moraine, a terminal moraine deposited during Keewatin glaciation (Blyth and Hudson 1987). Vegetation in the region is considered to be an outlier of the Lower Boreal Mixedwood ecoregion directly to the north (Strong 1992). The area is characterized by strongly undulating topography and is approximately $60 \mathrm{~m}$ higher in elevation than the surrounding plains.

Soils are variable throughout the Park, but are mostly Orthic Grey Luvisols on uplands having developed under deciduous forest. Gleysolic and organic soils are common in depressional wetlands, with the latter associated with flooded fens and bogs (Crown 1977). In addition, a smaller region of Solonetzic soil exists.

Although the majority of the Park is forested with Populus tremuloides and $P$. balsamifera L., numerous grasslands remain within the Park. Upland grasslands are dominated primarily by invasive grasses such as Poa pratensis L., Bromus inermis Leyss., and Agropyron repens (L.) Beauv., with Trifolium repens L. and Taraxacum officinale Weber co-dominant forbs. Native species include Agropyron trachycaulum (Link) Malte, Calamagrostis canadensis (Michx.) Beauv., and Puchinellia nuttalliana (Schult.) A.S. Hitchc. Lowland grasslands are dominated almost exclusively by Calamagrostis canadensis and various wetland Carex spp., including $C$. atherodes Spreng. and $C$. aquatilis Wahlenb. Solonetzic soils are dominated by Koeleria macrantha (Ledeb.) and Beckmannia syzigachne (Steud.) Fern. (Blyth and Hudson 1987).

\section{Methods}

To develop the relationship between precipitation and herbage production, data from the long-term rangeland monitoring sites distributed throughout the Park's 194 $\mathrm{km}^{2}$ were used. Although the data available for upland range sites is nearly continuous for the years spanning the monitoring period 1984 to 1996 , no data was available from 1986 because of Park staffing changes at that time. In addition, because 'year' was considered to be the experimental unit in this investigation, only those sites for which production data 
was consistently available over all years were used in the analysis (i.e., intra-annual herbage production was averaged across all range sites). This process excluded several sites from the investigation that were added or removed at intermediate stages during the monitoring period. Two additional upland monitoring sites were excluded from the investigation due to poor range condition associated with excessive grazing (Blyth et al. 1993): one due to excessive ungulate use and the other to Richardson's ground squirrels (Spermophilus richardsonii). Both sites were removed before any analysis was conducted and only after consultation with Park staff regarding the condition of sites.

Monitoring sites were approximately evenly distributed between upland grasslands and lowland sedge meadows. At each site, a minimum of 4 range cages, 1.5 by $1.5 \mathrm{~m}$ in size, were used to exclude ungulate herbivory for the growing season, with peak production clipped annually the first 2 weeks of September. Other work within the Park (unpublished data) indicates that 4 plots are sufficient to stabilize individual estimates of herbage production within sampled grasslands. Range cages were re-randomized to new locations on each site every spring prior to the onset of vegetation green-up.

Original clip sizes were $1 \mathrm{~m}^{2}$, but were reduced to $0.25 \mathrm{~m}^{2}$ (50 by $50 \mathrm{~cm}$ ) in 1993 to improve sampling efficiency. All current annual vegetative growth was clipped at ground level and sorted into herbage and shrub components. Shrub growth was minimal and therefore excluded from the analysis. All clips samples were ovendried at $75^{\circ} \mathrm{C}$ for 24 hours, and weighed to determine mean herbage production $\left(\mathrm{kgha}^{-1}\right)$ for each site, with all sites averaged to determine overall rangeland herbage production per year for the entire Park.

\section{Data Analysis}

Data were analyzed separately for upland and lowland areas due to the different dominant plant species, soil types, moisture regimes, and microclimates found within each area. The collection of lowland production data did not begin until the late 1980's, and as such, was pooled from 5 sites within each year for the period 1988 to 1996 , inclusive ( $n=9$ years). Upland productivity data were also pooled for 5 sites in each of the years from 1984 to 1996 , inclusive, but excluded $1986(\mathrm{n}=12$ years $)$.

In addition to the upland grasslands, 2 additional sites were examined separately from the rest as they were located on

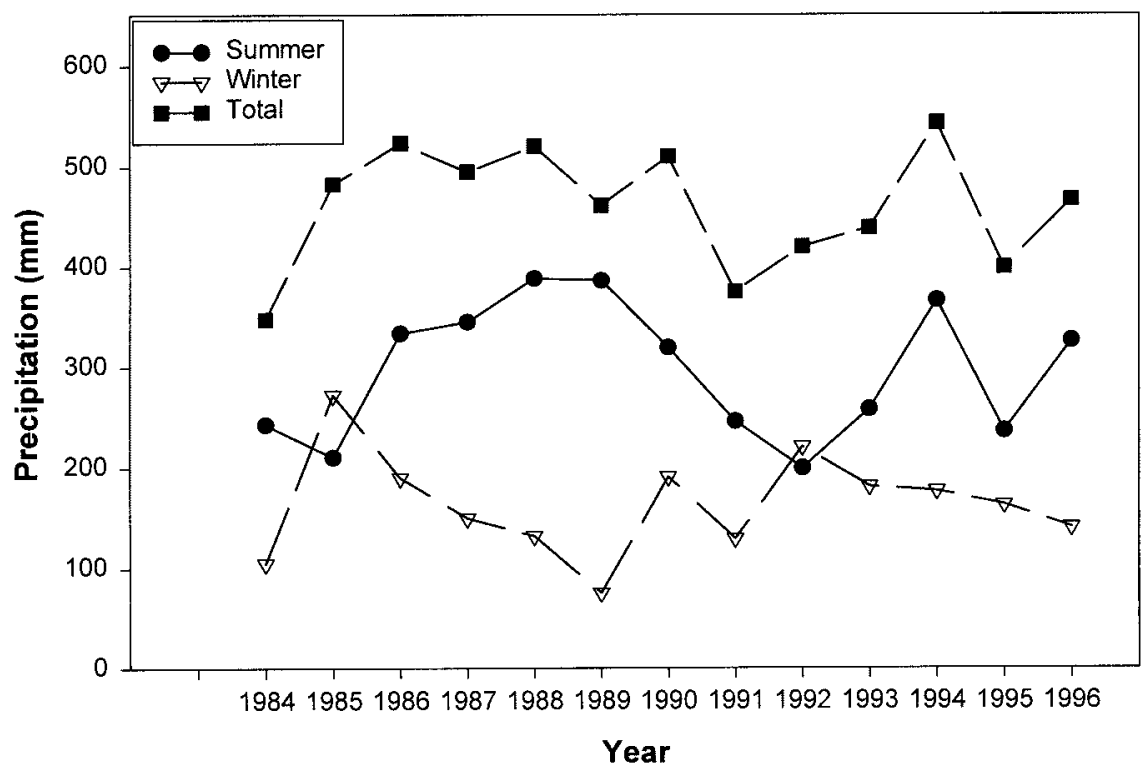

Fig. 1. Winter (Sept. to April), summer (May to August), and total (Sept. to August) precipitation for Elk Island National Park, from September 1983 to August, 1996.

Solonetzic soils within the Park $(n=8$ years). These areas, because of their unique soil features and obvious limitations in terms of plant growth, were of additional interest to Park managers and thus, included within the analysis.

Precipitation data was obtained from an Environment Canada weather station centrally situated within the Park. The maximum linear distance of the most distant sampling site from the station was approximately $16 \mathrm{~km}$, with most sites within a radius of $12 \mathrm{~km}$. For the analysis, 4 time intervals were chosen: 2 current year periods including May to August (4 month current growing season) and April to August (5 month extended growing season), as well as 2 water year periods. The latter included the preceding September to current August (12 month) period, as well as the preceding May to current August (16 month) period. These were chosen to assess the importance of previous year moisture recharge in affecting herbage production, as several studies have highlighted the importance of recharge moisture in contributing to forage production (e.g., Noller 1968, Smoliak 1986). Actual precipitation data for the area over the duration of the study are shown in Figure 1 , with the precipitation variables summarized in Table 1. Four month growing season precipitation averaged $322 \mathrm{~mm}$, ranging from 200 to $389 \mathrm{~mm}$ during 1984 to 1996. In contrast, 12 month water year precipitation averaged $477 \mathrm{~mm}$, varying from 375 to $557 \mathrm{~mm}$.

Initially, linear regression of precipitation with herbage yield was used to assess the predictability of forage production (dependent variable) from precipitation. Second order regressions were also performed, with increases in $\mathrm{R}^{2}$ evident for the lowland data (e.g., increases in $\mathrm{R}^{2}$ ranged from 0.04 to 0.27 ). Significance parameters were used to assess the reliability of all resulting regressions, facilitating comparisons between upland and lowland data sets, as well as between data sets involving current year and water year precipitation.

\section{Results and Discussion}

Average herbage production for all sites in each year are shown in Table 1. Lowlands yielded nearly twice the herbage from upland sites. This difference is likely due to the shortage of water that occurs on uplands in mid to late summer after soil moisture reserves are depleted and rainfall is unable to meet evapo-transpiration demands. The Solonetzic sites sampled yielded slightly more than the upland sites, but well below the lowland sites (Table 1). These areas benefit from being lower in elevation than upland sites and therefore, have an increased susceptibility to spring flooding, but suffer from the presence of a clay hardpan and elevated salt levels, which limit plant growth and overall productivity.

Absolute linear correlation coefficients among the 12 regressions varied from 0.35 to 0.76 (Table 2). The greatest correlations with herbaceous production were evident for upland grasslands using current year precipitation data (Table 2; Fig. 2a). Both 4 and 5 month current year (e.g., growing season) precipitation exhibited significant positive relationships $(\mathrm{p}<0.01)$ with 
Table 1. Average grassland herbage yields and precipitation levels for EINP from 1984 to 1996.

\begin{tabular}{|c|c|c|c|c|c|c|c|}
\hline \multirow[b]{2}{*}{ Year } & \multicolumn{3}{|c|}{ Average Annual Forage Yield } & \multicolumn{2}{|c|}{ Current Year Precipitation } & \multicolumn{2}{|c|}{$\begin{array}{l}\text { Water Year } \\
\text { Precipitation }\end{array}$} \\
\hline & $\begin{array}{l}\text { Upland } \\
(\mathrm{n}=12)\end{array}$ & $\begin{array}{l}\text { Solonetz } \\
\qquad(\mathrm{n}=8)\end{array}$ & $\begin{array}{l}\text { Lowland } \\
(n=9)\end{array}$ & $\begin{array}{c}\text { May - Aug. } \\
\text { (4 month) }\end{array}$ & $\begin{array}{l}\text { April - Aug. } \\
\text { (5 month) }\end{array}$ & $\begin{array}{l}\text { Prev. Sept.- F } \\
\text { Aug. } \\
\text { (12 month) }\end{array}$ & $\begin{array}{c}\text { Prev. May - } \\
\text { Aug. } \\
\text { (16 month) }\end{array}$ \\
\hline & $-\ldots \ldots$ & $\left(\mathrm{kg} \cdot \mathrm{ha}^{-1}\right)-$ & $-\ldots--$ & $---(1$ & nm) - - - - & $-\cdots(\mathrm{mm}$ & a ) - - - \\
\hline 1984 & 3174 & & & 243 & 258 & 426 & 735 \\
\hline 1985 & 1080 & & & 211 & 253 & 483 & 726 \\
\hline $1986^{*}$ & $\mathrm{n} / \mathrm{a}$ & & & 334 & 358 & 557 & 767 \\
\hline 1987 & 2931 & & & 345 & 346 & 495 & 829 \\
\hline 1988 & 3278 & 2891 & 5111 & 389 & 414 & 521 & 866 \\
\hline 1989 & 4554 & 4901 & 4595 & 387 & 397 & 502 & 890 \\
\hline 1990 & 3218 & 3390 & 5030 & 320 & 345 & 511 & 897 \\
\hline 1991 & 2721 & 2373 & 7889 & 246 & 264 & 375 & 694 \\
\hline 1992 & 2318 & 2372 & 5474 & 200 & 241 & 420 & 666 \\
\hline 1993 & 3207 & 3180 & 5889 & 258 & 301 & 439 & 639 \\
\hline 1994 & 4287 & 4780 & 6113 & 367 & 374 & 543 & 801 \\
\hline 1995 & 2722 & 4536 & 6418 & 236 & 263 & 400 & 766 \\
\hline 1996 & 3954 & & 7954 & 326 & 362 & 467 & 703 \\
\hline Mean & 3120 & 3553 & 6053 & 291 & 322 & 477 & 775 \\
\hline SD & 920 & 1047 & 1201 & 67.8 & 57.9 & 56.8 & 84.9 \\
\hline
\end{tabular}

upland herbage production (Table 2). In contrast, water year precipitation was a poorer predictor of herbage production on upland grasslands within the Park.

Overall, these correlations are lower than those reported by researchers conducting similar studies within the northern plains. For example, in SE Kansas, Shiftlet and Dietz (1974) found May to September (inclusive) precipitation was highly correlated with total growing season production $(\mathrm{r}=0.893)$. Working in southern Alberta, Smoliak (1956) also found a high correlation $(r=0.859)$ for May and June precipitation with production. Both of these studies, however, were conducted in prairie environments, where production is expected to depend heavily on growing season precipitation. The results found in our study suggest that similar to the Mixed Prairie, Boreal upland grassland production is heavily dependent on summer pre- cipitation, and as a result, these areas remain prone to significant variations in forage production with summer drought. Spatial separation between forage saming station may also have contributed some error into the regression relationships (Perry 1976).

The relatively poor relationship observed between water year precipitation and upland herbage production is contrary to the findings of Smoliak (1986) and Johnston et al. (1969), who found that Dry Mixed Prairie production in southern Alberta was best explained by incorporating fall precipitation. This may be due to the topographical differences found within Boreal and Mixed Prairie landscapes. Dormant season moisture recharge would only be expected to enhance forage production if contributing to soil moisture availability. Boreal environments, to pling sites and the precipitation monitor- which the park is no exception, often consist of steeply sloped topography (e.g., gradients of 5-15\%). Coupled with deeply frozen ground for 6 months or more during the winter, any snow falling and melting during the dormant season is likely to run off from these areas. Furthermore, snow is more likely to be redistributed from uplands to low-lying topographic positions during the winter months with drifting, rendering it inaccessible when spring growth resumes. Although runoff losses have been cited as one of the potential factors limiting the effectiveness of heavy summer rainfall in prairie environments (e.g., Albertson and Weaver 1942), the Dry Mixed Prairie landscapes of southern Alberta are generally flatter than those in the Boreal region. Coupled with milder and shorter winters, opportunities for water infiltration are likely greater, which may make these rangelands less susceptible to seasonal water re-distribution in the landscape.

Upland grasslands within the Park have been documented as generally in poor to fair range condition (Blyth et al. 1993, Bork et al. 1997). As a result, there is the possibility that part of the sensitivity of herbage production to precipitation variability is attributable to range condition. Despite this, other studies correlating production with precipitation indicate that while degradation associated with overgrazing may exacerbate forage reductions during drought years, productivity often continues to be more sensitive overall to changes in precipitation than grazing intensity (e.g., Milchunas et al. 1994). In addition, it must be noted that the poor condition ratings in the Park are primarily due to the abundance of undesirable introduced (e.g., exotic) plant species such as Kentucky bluegrass (Poa pratensis L.), rather than actual declines in plant vigor or

Table 2. Results of the regression of precipitation on herbage production for EINP.

\begin{tabular}{|c|c|c|c|c|c|c|}
\hline \multirow[b]{2}{*}{ Area: } & \multirow[b]{2}{*}{ Years: } & \multirow[b]{2}{*}{ Precipitation Variable*: } & \multicolumn{2}{|c|}{ Simple Correlation } & \multicolumn{2}{|c|}{ Second-Order Regress. } \\
\hline & & & $(\mathrm{r}):$ & p-value: & Model $\mathrm{R}^{2}$ : & p-value: \\
\hline Uplands & $\begin{array}{c}1984-1996 \\
\text { (omitting '86) } \\
(n=12)\end{array}$ & $\begin{array}{l}\text { CY-May to August } \\
\text { CY-April to August } \\
\text { WY-Sept. to Aug. } \\
\text { WY-May to Aug. }\end{array}$ & $\begin{array}{l}0.76 \\
0.74 \\
0.45 \\
0.41\end{array}$ & $\begin{array}{l}p<0.01 \\
p<0.01 \\
p=0.20 \\
p=0.25\end{array}$ & $\begin{array}{l}- \\
- \\
-\end{array}$ & $\begin{array}{l}- \\
- \\
-\end{array}$ \\
\hline Solonetz & $\begin{array}{c}1988-1995 \\
(n=8)\end{array}$ & $\begin{array}{l}\text { CY-May to August } \\
\text { CY-April to August } \\
\text { WY-Previous Sept. to Aug. } \\
\text { WY-Previous May to Aug. }\end{array}$ & $\begin{array}{l}0.50 \\
0.44 \\
0.45 \\
0.50\end{array}$ & $\begin{array}{l}\mathrm{p}=0.21 \\
\mathrm{p}=0.28 \\
\mathrm{p}=0.27 \\
\mathrm{p}=0.21\end{array}$ & $\begin{array}{l}- \\
-\end{array}$ & $\begin{array}{l}- \\
-\end{array}$ \\
\hline Lowlands & $\begin{array}{c}1988-1996 \\
(n=9)\end{array}$ & $\begin{array}{l}\text { CY-May to August } \\
\text { CY-April to August } \\
\text { WY-Previous Sept. to Aug. } \\
\text { WY-Previous May to Aug. }\end{array}$ & $\begin{array}{l}-0.35 \\
-0.35 \\
-0.54 \\
-0.61\end{array}$ & $\begin{array}{l}p=0.36 \\
p=0.35 \\
p=0.14 \\
p=0.08\end{array}$ & $\begin{array}{l}0.36 \\
0.23 \\
0.33 \\
0.64\end{array}$ & $\begin{array}{l}\mathrm{p}=0.26 \\
\mathrm{p}=0.46 \\
\mathrm{p}=0.30 \\
\mathrm{p}<0.05\end{array}$ \\
\hline
\end{tabular}

* CY - denotes current year precipitation; WY - denotes water year precipitation, which includes the previous summer and/or dormant season recharge period. 

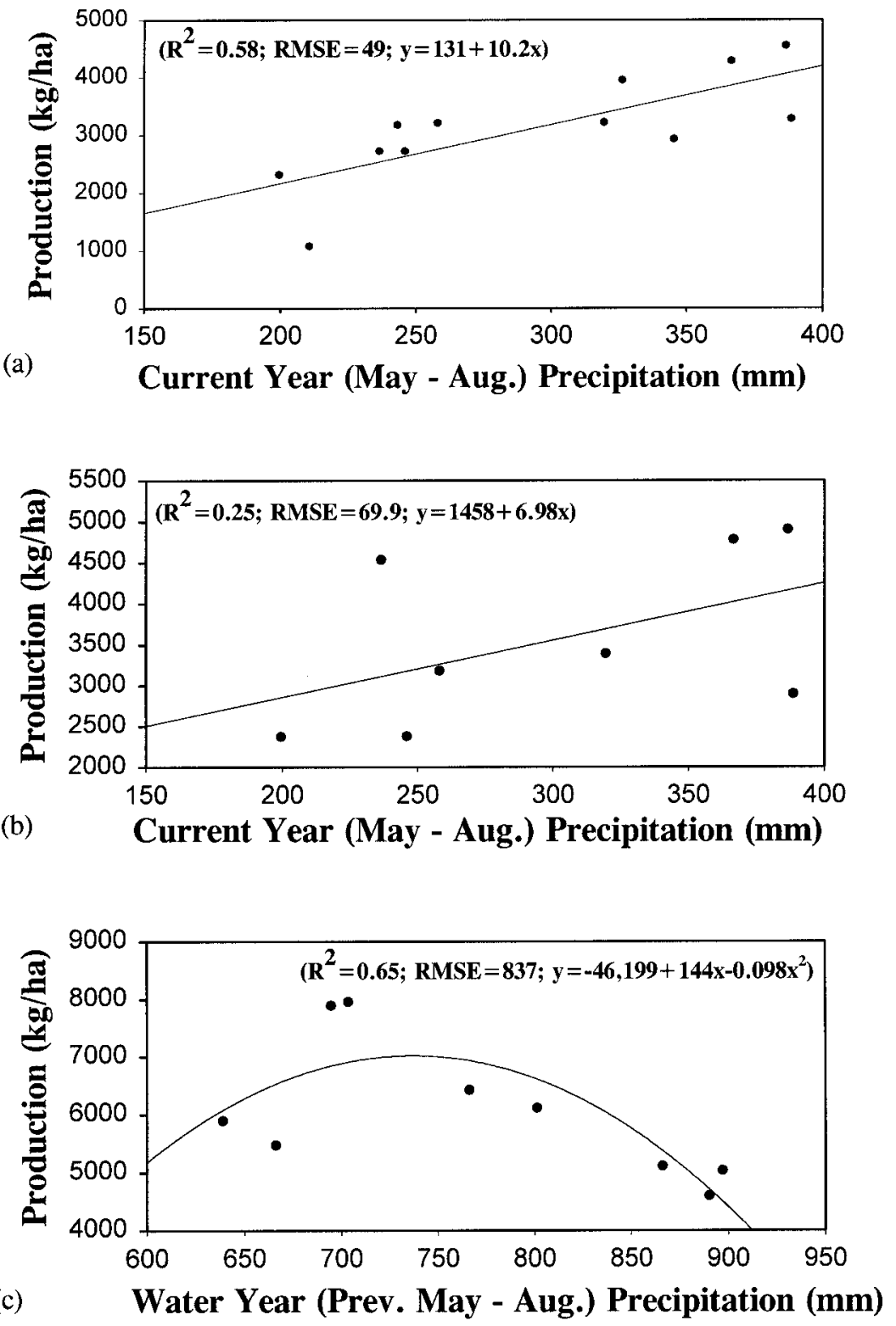

Fig. 2. Regressions of the leading climatic variable with herbage production for each of the (a) upland grasslands, (b) Solonetzic sites, and (c) lowland grasslands.

site degradation such as soil erosion. Repeated grazing in the past may also have altered the effectiveness of nitrogen cycling on uplands, particularly within a National Park where intensive management (e.g., fertilization) never occurs. Repeated vegetation removal coupled with nutrient redistribution and losses from animal waste (Parton and Risser 1980), may have produced soil $\mathrm{N}$-impoverished plant communities limited in their ability to respond to increased rainfall.

Separate regression analysis of the 2 sampling sites on Solonetzic soils showed a weak positive relationship $(p=0.21)$ for each of the 4 precipitation variables inves- tigated (Table 2, Fig. 2b). Solonetzic soils are characterized by a highly compacted clay pan B-horizon, which impedes water and air penetration as well as root development. Perched water tables are common above the B horizon, and high sodium levels may further limit the water available to plants. Plant growth is spatially patchy, with production probably linked to a complex of factors, including species composition, opportunities for root development, and moisture availability. Salt concentrations, which can reach levels that inhibit growth, vary widely over short distances (Cairns and Bowser 1977). Spatial heterogeneity within these areas is also likely to complicate the accurate assessment of herbage production. The weak positive correlation between herbage production and current year precipitation on Solonetzic soils (Fig. 2b) may arise from enhanced moisture availability within the perched water table, as well as the direct dilution of salts (Donahue et al. 1977).

Similar to upland areas, lowland herbage production displayed a significant $(\mathrm{p}<0.05)$ relationship with precipitation (Table 2). Unlike the uplands, however, this relationship followed a negative curvilinear function (Fig. 2c). This suggests that within the Boreal environment, levels of precipitation above a specific threshold impede rather than enhance plant growth within wetlands.

The negative response of lowland herbage to high precipitation is most likely linked to soil temperatures. Average growing seasons within the Boreal region are less than 90 days (Strong 1992). Wet or saturated soils take longer to warm in the spring than well-drained uplands, delaying and slowing plant growth throughout the spring and into summer (Donahue et al. 1977). The length of the effective growing season within these areas may fall to levels well below 90 days. Excess moisture may also create a soil environment that is oxygen deficient, lowering root respiration and subsequent plant growth.

The negative effect of precipitation on lowland herbage production also appears to be linked to the timing of precipitation. Overall, water year precipitation resulted in improved relationships with herbage production than current year precipitation (Table 2). When regressed as a second order polynomial against herbage production, 16 month water year precipitation produced a superior fit to all other precipitation variables (Fig. 2c). These results are likely attributable to lowlands accumulating much of the redistributed snow and surface runoff (e.g., meltwater) deposited the previous fall and winter. Hence, greater overwinter precipitation is more likely to delay spring growth. Rumberg and Sawyer (1965) tested the production response of native wet meadows to flooding and found similar results. They concluded that while shallow flooding increased total production, flooding depths equal or greater than 5 inches $(12.5 \mathrm{~cm})$, and which were 50 days or longer in duration, actually reduced yields. The relatively greater dependency of lowland production on 16 month water year demonstrated here may indicate that moisture recharge begins either well in advance of the previous fall, or that elevated sequential grow- 
ing season and dormant season precipitation may compound one another to further restrict lowland herbage growth the following year.

Overall, these results indicate that Boreal grassland production is very site (e.g., topographic position) specific, a trend which has been observed in prairie ecosystems by other researchers (Wight et al. 1984). As a result, generic relationships relating precipitation to forage production should be avoided. For example, it has been shown that different soil types with differing production capabilities are not directly applicable to other areas (Sneva and Hyder 1962). In this study, topographic position interacted with precipitation to effect herbage production. This supports the notion that production models should not be used for sites and environmental conditions beyond that from which they were developed. These findings agree, however, with the conclusion of Collins and Weaver (1978), that precipitation levels can be an effective determinant of herbage production, provided it is recognized that the actual response will depend heavily on the timing and nature of the precipitation, as well as the potential of the specific plant community to respond to increased moisture.

\section{Conclusion}

Contrary to the frequently held notion that moisture is non-limiting for plant growth within the boreal region, upland herbage production within boreal grasslands is directly dependent on precipitation, particularly that which falls during the growing season (May to August). These results parallel those found for the major prairie rangeland ecosystems in western Canada, and have implications for ranchers and rangeland managers working within boreal ecosystems.

Although upland production is positively correlated with precipitation, lowland meadows appear to be negatively effected by high levels of precipitation. In these situations, the accumulation of excessive moisture, particularly during the previous dormant season when precipitation and snowmelt may accumulate within lowlands, appears to reduce herbage production. These results indicate that topographic position is an equally important factor to consider in the modeling of herbage production in relation to precipitation, particularly within boreal environments.

\section{Literature Cited}

Albertson, F.W. and J.E. Weaver. 1942. History of the native vegetation of western Kansas during seven years of continous drought. Ecol. Monogr. 12:23-51.

Ballard, W. and D.E. Ryerson. 1973. Impacts of induced rainfall on the Great Plains of Montana-Section 1: Range livestock production. Montana Agr. Exp. Sta. Res. Paper 42.

Blyth, C.B. and R.J. Hudson. 1987. Vegetation and ungulate management plan for Elk Island National Park. Unpubl. Parks Canada Rep., Elk Island National Park.

Blyth, C.B., N.L. Cool, A. Dickinson, R. Kaye, W.E. Olson, T. Osko, D.S. Madsen, and B. McDougall, B. 1993. Ecosystem status and management recommendations, Elk Island National Park. Unpubl. Parks Canada Rep., Heritage Resource Conse., Elk Island National Park.

Bork, E.W., R.J. Hudson, and A.W. Bailey. 1997. Upland plant community classification in Elk Island National Park, Alberta, Canada, using disturbance history and physical site factors. Plant Ecol. 130:171-190.

Cannon, M.E. and G.A. Nielson. 1984. Estimating production of range vegetation from easily measured soil characteristics. Soil Sci. Soc. Amer. J. 48: 1393-1397.

Cairns, R.R. and W.E. Bowser. 1977. "Solonetzic soils and their management". Agr. Canada. Pub. 1391.

Clarke, S.E., E.W. Tisdale, and N.A. Skoglund. 1947. The effects of climate and grazing practices on short-grass prairie vegetation. Dominion Dept. Agr. Tech. Bull. 46.

Collins, D. and T. Weaver. 1978. Effects of summer weather modification (irrigation) in Festuca idahoensis-Agropyron spicatum grasslands. J. Range Manage. 31: 264-269.

Coupland, R.T. 1958. The effects of fluctuations in weather upon grasslands of the Great Plains. Bot. Rev. 24:273-317.

Crown, P.H. 1977. Soil survey of Elk Island National Park, Alberta. Alberta Institute of Pedology. Rep. S-77-38.

Donahue, R.L., R.W. Miller, and J.C. Shickluna. 1977. Soils: an introduction to soils and plant growth. Prentice-Hall Inc. Englewood Cliffs, N.J.

Epstein, H.E., W.K. Lauenroth, and I.C. Burke. 1997. Effects of temperature and soil texture on ANPP in the U.S. Great Plains. Ecol. 78:2628-2631.

Haferkamp, M.R., J.D. Volesky, M.M. Borman, R.K. Heitschmidt, and P.O. Currie. 1993. Effects of mechanical treatments and climatic factors on the productivity of Northern Great Plains rangelands. J. Range Manage. 46:346-350.

Hulett, G.K. and G.W. Tomanek. 1969. Forage production on a clay upland range site in western Kansas. J. Range Manage. 22: 270-276.

Johnston, A., S. Smoliak, D. Smith, and L.E. Lutwick. 1969. Season precipitation, evaporation, soil moisture, and yield of fertilized range vegetation. Can. J. Plant Sci. 49:123-128.
Lauenroth, W.K. and O.E. Sala. 1992. Long term forage production of North American shortgrass steppe. Ecol. Appl. 2:397-403.

Milchunas, D.G., J.R. Forwood, and W.K. Lauenroth. 1994. Productivity of long-term grazing treatments in response to seasonal production. J. Range Manage.47:133-139.

Noller, G.L. 1968. The relationship of forage production to precipitation, cover, and soils in North Central Wyoming. Univ. Wyoming, Laramie, Ph.D. Thesis.

Parton, W.J. and P.G. Risser. 1980. Impact of management practices on the tallgrass prairie. Oecologia (Berlin) 46:223-234.

Perry, D.A. 1976. The effects of weather modification on northern Great Plains grasslands: a preliminary assessment. J. Range Manage. 29:272-277.

Rauzi, F. 1964. Late-spring herbage production on shortgrass rangeland. J. Range Manage. 17:210-212.

Rogler, G.A. and H.J. Haas. 1947. Range production as related to soil moisture and precipitation on the Northern Great Plains. J. Amer. Soc. Agron. 39:378-389.

Rowe, J.S. 1959. Forest regions of Canada. Can. For. Branch Bull. 123:1-71.

Rumberg, C.B. and W.A. Sawyer. 1965. Response of wet-meadow vegetation to length and depth of surface water from wildflood irrigation. Agron. J. 57: 245-247

Shiflet, T.N. and H.E. Dietz. 1974. Relationship between precipitation and annual rangeland herbage production in S.E. Kansas. J. Range Manage. 27:272-276.

Smoliak, S. 1956. Influence of climatic conditions on forage production of shortgrass rangeland. J. Range Manage. 9:89-91.

Smoliak, S. 1986. Influence of climatic conditions on production of Stipa-Bouteloua Prairie over a 50-year period. J. Range Manage. 39:100-103.

Sneva, F.A. and D.N. Hyder. 1962. Estimating herbage production on semiarid ranges in the intermountain region. J. Range Manage. 15:88-93.

Strong, W.L. 1992. Ecoregions and ecodistricts of Alberta. Alberta Energy and Natural Resources. Edmonton, AB. Pub. T/244.

Telfer, E.S. 1972. Range trend studies at Elk Island National Park. Unpubl. Rep, Canadian Wildl. Serv., Edmonton, Alberta.

Van Ryswyk, A.L., K. Broersma, and J.W. Hall. 1995. Livestock use and extent of wetlands on the central interior plateaux of British Columbia, Canada. Pp. 583-584. In: N.E. West (ed.), Proc. $5^{\text {th }}$ Int. Rangeland Congr., Salt Lake City, Utah.

Willoughby, M.G., K. Sundquist, and D. Downing. 1996. Range plant community types and carrying capacity for the Dry and Central Mixedwood Subregions. Environ. Protection, Lands and Forest Serv., Pub. T/395.

Wight, J.R., C.L. Hanson, and D. Whitmer. 1984. Using weather record with a forage production model to forecast range forage production. J. Range Manage. 37:3-6. 